\title{
Hyponatremia in children with respiratory tract infection
}

\author{
Kazunari Kaneko $\cdot$ Ken-ichiro Kaneko
}

Received: 26 January 2009 /Accepted: 27 January 2009/Published online: 18 March 2009

(C) IPNA 2009

Sirs,

We read with great interest the article entitled "Hyponatremia in pediatric community-acquired pneumonia" by Don et al. in the latest issue of this journal [1], and we congratulate their elegant study.

They concluded that hyponatremia $(\mathrm{HN})$ is common (present in $45.4 \%$ of children with community-acquired pneumonia) and seems to be associated with the severity, assessed by fever, need of hospitalization and serum nonspecific inflammatory markers.

We would like to add a comment based on our retrospective analysis. In 2004 we encountered serial patients with $\mathrm{HN}$ who had ben admitted to our hospital because of respiratory tract infection (RTI). This experience prompted us to investigate the prevalence of $\mathrm{HN}$ in children with RTI: the medical records of 138 children with RTIs admitted in 2004 (mean age 2.2 years, range $0.1-11.6$ years) were reviewed retrospectively. These children had been previously healthy and did not have any underlying illness which predisposed them to $\mathrm{HN}$, such as renal, thyroidal, adrenal or hypophyseal insufficiency.

As shown in the table, there were 40 children $(28.9 \%)$ with RTIs showing HN (serum sodium $<136 \mathrm{mmol} / \mathrm{L}$ ). There were no significant differences in age or duration of hospital stay between children with $\mathrm{HN}$ and those without $\mathrm{HN}$ : age $2.72 \pm$ 2.55 years (mean \pm standard deviation) for the former and $2.03 \pm 2.09$ years for the latter; duration of hospital stay $7.00 \pm$ 3.38 days (mean \pm standard deviation) for the former and $6.04 \pm$ 3.82 days for the latter $(P>0.05$ by unpaired Student's $t$-test). Furthermore, the 138 patients with RTIs were divided into three groups according to the site of inflammation, based on

K. Kaneko $(\bowtie)$

Department of Pediatrics, Kansai Medical University,

2-3-1 Shin-machi, Hirakata-shi,

Osaka 573 1191, Japan

e-mail:kanekok@hirakata.kmu.ac.jp

K.-i. Kaneko

Department of Pediatrics, Juntendo University Urayasu Hospital,

Chiba, Japan the clinical and radiological findings (Table 1). Interestingly enough, the deeper the site of inflammation, the higher the prevalence of $\mathrm{HN}$.

There have been several reports regarding $\mathrm{HN}$ in children with pneumonia [1-4], including the study by Don et al. In those studies the authors speculated that the mechanism of HN in pneumonia is due to the syndrome of inappropriate antidiuretic hormone (ADH) secretion and found that $\mathrm{HN}$ was associated with the severity in pneumonia. In addition, we here would like to suggest that the deeper the site of inflammation in the respiratory tract, the higher the prevalence of $\mathrm{HN}$ in children with RTIs.

Table 1 Prevalence of hyponatremia in children admitted with respiratory tract infections (Department of Pediatrics, Juntendo University Urayasu Hospital)

\begin{tabular}{llll}
\hline $\begin{array}{l}\text { Main site of } \\
\text { inflammation }\end{array}$ & $\begin{array}{l}\text { Number of children } \\
\text { with hyponatremia }\end{array}$ & $\begin{array}{l}\text { Total } \\
\text { number } \\
\text { of subjects }\end{array}$ & $\begin{array}{l}\text { Prevalence } \\
(\%)\end{array}$ \\
\hline $\begin{array}{c}\text { Pharyngitis } \\
\text { or laryngitis }\end{array}$ & 2 & 15 & 13.3 \\
$\begin{array}{c}\text { Bronchitis or } \\
\text { bronchiolitis }\end{array}$ & 14 & 61 & 22.9 \\
$\begin{array}{c}\text { Pneumonia } \\
\text { Total number }\end{array}$ & 24 & 62 & 38.7 \\
\hline
\end{tabular}

\section{References}

1. Don M, Valerio G, Korppi M, Canciani M (2008) Hyponatremia in pediatric community-acquired pneumonia. Pediatr Nephrol 23:2247-2253

2. Shann F, Germer S (1985) Hyponatraemia associated with pneumonia or bacterial meningitis. Arch Dis Child 60:963-966

3. Singhi S, Dhawan A (1992) Frequency and significance of electrolyte abnormalities in pneumonia. Indian Pediatr 29:735-740

4. Dhawan A, Narang A, Singhi S (1992) Hyponatraemia and the inappropriate $\mathrm{ADH}$ syndrome in pneumonia. Ann Trop Paediatr $12: 455-462$ 